NBER WORKING PAPER SERIES

\title{
MEASURING WHAT EMPLOYERS REALLY DO ABOUT ENTRY WAGES OVER THE BUSINESS CYCLE
}

\author{
Pedro S. Martins \\ Gary Solon \\ Jonathan Thomas \\ Working Paper 15767 \\ http://www.nber.org/papers/w15767 \\ NATIONAL BUREAU OF ECONOMIC RESEARCH \\ 1050 Massachusetts Avenue \\ Cambridge, MA 02138 \\ February 2010
}

The authors are grateful for helpful discussions with Michael Elsby and Pedro Portugal and for comments from seminar participants at Michigan State University, the National Bureau of Economic Research Summer Institute, the CREI/Kiel Institute conference on "Macroeconomic Fluctuations and the Labor Market," and the International Tor Vergata Conference on Money, Banking, and Finance. Martins and Thomas are grateful for the support of the ESRC (RES-062-23-0546). The views expressed herein are those of the authors and do not necessarily reflect the views of the National Bureau of Economic Research.

NBER working papers are circulated for discussion and comment purposes. They have not been peerreviewed or been subject to the review by the NBER Board of Directors that accompanies official NBER publications.

(C) 2010 by Pedro S. Martins, Gary Solon, and Jonathan Thomas. All rights reserved. Short sections of text, not to exceed two paragraphs, may be quoted without explicit permission provided that full credit, including $(\subset$ notice, is given to the source. 
Measuring What Employers Really Do about Entry Wages over the Business Cycle Pedro S. Martins, Gary Solon, and Jonathan Thomas

NBER Working Paper No. 15767

February 2010

JEL No. E24,E32

\begin{abstract}
$\underline{\text { ABSTRACT }}$
In models recently published by several influential macroeconomic theorists, rigidity in the real wages that firms pay newly hired workers plays a crucial role in generating realistically large cyclical fluctuations in unemployment. There is remarkably little evidence, however, on whether employers' hiring wages really are invariant to business cycle conditions. We review the small empirical literature and show that the methods used thus far are poorly suited for identifying employers' wage practices. We propose a simpler and more relevant approach - use matched employer/employee longitudinal data to identify entry jobs and then directly track the cyclical variation in the real wages paid to workers newly hired into those jobs. We illustrate the methodology by applying it to data from an annual census of employers in Portugal over the period 1982-2007. We find that real entry wages in Portugal over this period tend to be about 1.8 percent higher when the unemployment rate is one percentage point lower. Like most recent evidence on other aspects of wage cyclicality, our results suggest that the cyclical elasticity of wages is similar to that of employment
\end{abstract}

Pedro S. Martins

School of Business and Management

Queen Mary, University of London

London E1 4NS

UK

p.martins@qmul.ac.uk

Gary Solon

Department of Economics

Marshall-Adams Hall

Michigan State University

East Lansing, MI 48824-1038

and NBER

solon@msu.edu
Jonathan Thomas

School of Economics

University of Edinburgh

Edinburgh EH8 9JY

UK

Jonathan.Thomas@ed.ac.uk 


\section{Measuring What Employers Really Do about Entry Wages over the Business Cycle}

\section{Introduction}

Recent theoretical efforts to explain the amplitude of cyclical unemployment fluctuations have emphasized the potential importance of rigidity in the real wages that firms pay to their newly hired workers. But are firms’ hiring wages really acyclical?

In section II, we review the recent theoretical literature. In section III, we argue that the empirical literature has not succeeded yet in identifying what employers really do about hiring wages, and then we propose a more direct and transparent empirical approach - using matched employer/employee longitudinal data to identify firms’ entry jobs and then tracking the cyclical variation in the real wages paid to workers newly hired into those jobs. In section IV, we illustrate our approach with an application to data from the annual census of employers in Portugal. In section $\mathrm{V}$, we briefly summarize our findings, and we discuss their macroeconomic implications.

\section{The Macroeconomic Importance of Entry-Wage Cyclicality}

At least since Keynes (1936), macroeconomists have theorized that wages are inflexible and that limited cyclical variability of wages may account for the cyclical volatility of employment and unemployment. The idea continues to figure prominently in the current literature. For example, the very first sentence of the recent Journal of Political Economy paper by Gertler and Trigari (2009, p. 38) says, “A long-standing challenge in macroeconomics is accounting for the relatively smooth behavior of real wages over the business cycle along with the relatively volatile behavior of employment.” 
Much of the current interest in the cyclical behavior of wages, especially hiring wages, has grown out of a debate about the ability of the canonical Mortensen-Pissarides (1994) model to generate realistically large cyclical fluctuations in unemployment. In the canonical model, wages within a worker/employer match are determined by Nash bargaining, and this yields a solution where the wage depends on the worker's productivity in the match and the worker's outside option, which depends in turn on the value of search and non-market activities. Because the value of non-market activities is less cyclical than labor productivity, the wage does not vary as much as productivity, and employment is correspondingly more volatile. However, as pointed out by Shimer (2005), under standard parameter values, the outside option is almost as cyclical as productivity, with the implication that wages in the canonical model are likewise too cyclical to generate realistic levels of unemployment variability.

Consequently, several authors - such as Shimer (2004), Hall (2005), Hall and Milgrom (2008), Gertler and Trigari (2009), and Kennan (forthcoming) - have suggested wage stickiness as one way of generating more variability of unemployment within the model. Whether this is the right way to go, however, should ultimately be subject to empirical investigation. How much do wages actually vary over the business cycle?

Of course, there already is a great deal of evidence on certain aspects of that question. Numerous studies using longitudinal microdata have found that real wages are substantially procyclical. As will be discussed in the next section, many of those studies 
find particularly large wage cyclicality for job changers, with lesser (though considerable) cyclicality appearing for the wages of workers in ongoing matches. ${ }^{1}$

This apparent difference in wage cyclicality between incumbent and newly hired workers seems at odds with the canonical model, in which continuous Nash bargaining would cause wages in ongoing matches to be as procyclical as those in new matches. This is easily accommodated, though, by a sensible modification of the model. All that matters for the job creation incentive (what determines how many new jobs there are) is the expected (discounted) value of wages in the match, not how they are distributed over time, a point that has long been recognized (Becker, 1962; Barro, 1977; Hall, 1980; and Boldrin and Horvath, 1995) and has been reemphasized in the context of the current debate (Shimer, 2004; Haefke, Sonntag, and van Rens, 2008; and Pissarides, 2009). Hence, it is argued, all that is needed to square the model with the data is to incorporate a labor contract that makes ongoing wages relatively insensitive to future productivity changes, for example, by making workers slightly risk averse while maintaining the canonical model's assumption that firms are risk neutral. In such an environment, if both firm and worker could commit to a future wage path, ongoing wages would be constant but at a level influenced by productivity at the point of match initiation, so wages of new hires could vary procyclically while those of "stayers" would be acyclical. An approach along these lines then suggests that the wage in a new match would be persistent and the total cost of the worker - and hence the profitability of the match - would vary with the start wage.

\footnotetext{
${ }^{1}$ See Solon, Barsky, and Parker (1994) and the literature review in Solon, Barsky, and Parker (1992). For more recent studies focusing on wage cyclicality in ongoing matches, see Devereux (2001), Devereux and Hart (2006), and Shin and Solon (2007).
} 
In fact this goes too far to the other extreme as now stayers' wages are too rigid relative to the data. Rudanko (2009) incorporates Thomas and Worrall's (1988) model of "limited commitment" into a search-matching model, so that ongoing wages respond to compete with outside options and therefore display a degree of procyclicality. For example, Rudanko finds that, if neither firm nor worker can commit irreversibly to a future wage path, then the model can match the empirical aggregate wage volatility (and while she does not examine this, the continuing match wage will also be procyclical). However, the effect on magnifying unemployment and vacancy volatility is small essentially confirming the point that the distribution of wages over time in an ongoing match is unimportant.

This issue is considered further by Kudlyak (2007), who compares the cyclicality of the new hire wage with that of the "user cost of labor." The latter is defined to measure the cost of hiring a worker today relative to postponing this decision one period, and is the primary determinant of the current employment decision (as, in the equilibrium of her matching model, the marginal product of labor will equal the user cost). If a worker hired next period will be paid differently from a hire today, the user cost must take into account this future difference in addition to the current wage. Kudylak emphasizes that the user cost may be even more procyclical than the new hire wage. To understand this, consider a worker hired in a downturn, and suppose full commitment by both worker and firm is possible. The equilibrium contract will pay a relatively low and constant wage. However, because of mean reversion, productivity is expected to improve, so a worker hired next period is likely to receive a higher constant wage. Thus the cost of filling a position today rather than tomorrow is the current wage less the 
discounted future expected savings on the lower wage contract, and the user cost falls more than the new hire wage in a recession (and vice versa in a boom). Even when commitment is imperfect, a similar argument may apply if wages in ongoing matches are sufficiently inertial relative to productivity. ${ }^{2}$

To summarize, even if wages in ongoing employment relationships were sticky, the wages of new hires could be highly procyclical, and the allocative importance of start wages is all the greater the more persistent those wages are as the match continues. As recent theoretical analyses have shown, with sufficiently procyclical start wages, the problem of explaining the volatility of unemployment remains. But are entry wages really very procyclical? In the next section, we explain why existing evidence is not dispositive, and we introduce a more direct approach for measuring entry-wage cyclicality.

\section{Methods of Measuring Entry-Wage Cyclicality}

\section{A. Previous Empirical Studies}

Pissarides (2009) dismisses theories based on cyclically rigid wages on the ground that, empirically, hiring wages are quite procyclical. His main basis for the claim is a collection of microeconometric studies reporting that workers who change employers during expansions tend to experience much better wage growth than workers who change employers during recessions. Examples of such studies include Bils (1985) and Shin

\footnotetext{
${ }^{2}$ Kudlyak (2009) makes a heroic attempt to measure the cyclicality in the user cost of newly hired labor. The true value of that user cost as perceived by the employer depends on how long the employer believes the match will last, what the employer believes will be the future path of both the wage rate and the productivity of the match, and the employer's understanding of the interrelationships among these factors. For a data analyst to impute the employer's perception of the user cost therefore requires very strong assumptions. Based on the assumptions she makes, Kudlyak concludes that the user cost is more procyclical than the start wage.
} 
(1994) for the United States; Devereux and Hart (2006) for the United Kingdom; and Martins (2007) and Carneiro, Guimarães, and Portugal (2009) for Portugal. Similarly, Haefke, Sonntag, and van Rens (2008) find that individuals moving from nonemployment to employment during expansions tend to receive higher wages than individuals moving from non-employment to employment during recessions.

Gertler and Trigari (2009), however, explain why such evidence does not rule out acyclical wage setting by firms. Even if every firm maintains cyclically rigid wages in each job title, workers taking new jobs will show procyclical wages if, during expansions, they face better opportunities to move into higher-paying industries, higher-paying firms within industries, or higher-paying jobs within firms. In contrast, during recessions, a larger share of job changers are displaced workers, who often suffer wage reductions relative to the jobs they have lost. As Gertler and Trigari (p. 73) put it, "Suppose, for example, that a highly skilled machinist takes a job as a low-paid cab driver in a recession and then is re-employed as a high-paid machinist in a boom. In this case there is a cyclical movement in job match quality for the individual” even if the wages in both the machinist job and the cab driver job are acyclical. ${ }^{3}$ As Gertler and Trigari emphasize, this process of so-called "cyclical upgrading” in worker/employer matches (and cyclical downgrading in recessions) has long been discussed and documented. Early references include Reynolds (1951), Reder (1955), and Okun (1973). Recent analyses include Solon, Whatley, and Stevens (1997), McLaughlin and Bils (2001), and Devereux (2004).

We should note that, from the workers' perspective, their improved opportunities for moving to better jobs in an expansion are a true form of wage procyclicality. But that

\footnotetext{
${ }^{3}$ Bewley (1999, p. 151) earlier made the exact same point: "the findings could result from the effects of recession on the level of jobs accepted during recessions rather than from the effects on hiring pay for particular jobs.”
} 
is not what theoretical analyses such as Hall (2005) are about. Rather, those analyses are attempting to explain the amplitude of cyclical fluctuations in unemployment by assuming rigidity in the hiring wages that particular firms pay in particular jobs. Gertler and Trigari therefore are correct in criticizing the existing empirical literature for rejecting such theories on the basis of evidence confounded by cyclical upgrading/downgrading.

Gertler and Trigari claim to get better estimates of cyclicality of hiring wages within particular jobs by using longitudinal U.S. worker data from 1990-1996 in the Survey of Income and Program Participation. In particular, they perform least squares estimation of a regression of the worker's log real wage on the unemployment rate, the interaction of the unemployment rate with a dummy variable that equals 1 if the worker has been with the current employer for less than a year, dummy variables for every worker/employer match, and other control variables including the current tenure of the match. The estimated coefficient of the interaction term is statistically insignificant, and Gertler and Trigari (pp. 73-4) conclude that, "after we control for compositional effects, new hire wages appear no more cyclically sensitive than existing workers’ wages.”

It is crucial, however, to consider the properties of the sort of "fixed effects estimation” that Gertler and Trigari implement by controlling for worker/employer matches. As is well-known from the literature on longitudinal estimation, controlling for match-specific fixed effects is the same thing as using only the within-match variation in the other regressors to identify the coefficients of those regressors. ${ }^{4}$ As a result, what Gertler and Trigari's insignificant estimate for the coefficient of the interaction term really means is merely this - when one contrasts how a worker's wage moves with

\footnotetext{
${ }^{4}$ For example, see Wooldridge (2002, p. 273).
} 
changes in the unemployment rate during the first year with an employer (say, between the worker's second and sixth months with the employer) with how the same worker's wage moves with changes in the unemployment rate after the first year with the employer (say, between the fourteenth and eighteenth months of the match), the estimate of this contrast is statistically insignificant. As such, the estimated coefficient of the interaction term speaks only to a particular aspect of how workers' wages evolve after the workers already have been hired. It does not measure cyclicality in initial hiring wages. ${ }^{5}$

To summarize, we agree with Gertler and Trigari’s point that empirical assessment of recent theories of hiring-wage rigidity requires an approach that identifies cyclical variation in hiring wages within particular jobs. Their approach, however, does not achieve this. In the next sub-section, we propose an alternative approach that does track hiring wages in particular jobs.

\section{B. Our Methodology}

To get at the question that recent researchers intended to address, we propose a more direct and pertinent methodology - identify specific entry jobs within particular

\footnotetext{
${ }^{5}$ Where Gertler and Trigari control for match fixed effects, Carneiro, Guimarães, and Portugal (2009) (using the same Portuguese data base that we use) instead control for linearly separable worker fixed effects and firm fixed effects. Like the fixed effects estimation of Gertler and Trigari, the fixed effects estimation of Carneiro et al. does not seem to identify what the authors intend it to. First, controlling for linearly additive firm effects does not account for within-firm heterogeneity in match quality. Taking Gertler and Trigari's skilled machinist as an example, controlling for firm fixed effects successfully adjusts for that worker's cyclical upgrading only if the only reason the machinist is paid more by the firm that uses him as a machinist than the firm that uses him as a cab driver is that the first firm tends to pay all its workers more than the latter firm pays all its workers. Obviously, that need not be the case. Second, the particular regression model estimated by Carneiro et al. includes a dummy variable for matches in their first year (which switches off after the first year of the match) and an interaction of that dummy with the unemployment rate. The sum of the coefficient of the interaction term and the coefficient of the unemployment rate is taken to represent the overall cyclicality of hiring wages. Carneiro et al., however, do not justify that interpretation and, in certain cases, it clearly is incorrect. As a particularly simple example, consider the "full commitment" case in which a worker hired at a low wage during a recession is thereby locked into a low wage throughout the rest of the match. With identification coming off of the contrast between the first year and subsequent years of the match, this observation would bias the estimation away from finding a recession effect on the hiring wage.
} 
firms, track the wages paid to newly hired workers in those jobs, and measure how those entry wages vary over the business cycle. A precedent for this approach was applied by Solon, Whatley, and Stevens (1997, p. 412), who found that "the entry wage for 'laborers,' the most common occupation for newly hired workers” in the Byers iron tubing and pipe manufacturing company, was procyclical over the 1919-1932 period. That result, however, applied to only one company observed over 70 years ago. In the present paper, we take a similar approach with a large number of firms observed between 1982 and 2007 in an annual census of employers in Portugal. Because we hope that our approach eventually will be applied to other countries besides Portugal, here we describe the general methodology. Idiosyncrasies that arise in the application to the Portuguese data set will be addressed in section IV.

Let $w_{j t}$ denote the typical real wage paid in period $t$ to workers newly hired into job $j$, which is a particular job into which a particular firm does a substantial amount of its hiring of new employees. A convenient statistical model for $w_{j t}$ is

(1) $\quad \log w_{j t}=\alpha_{j}+\beta_{t}+\varepsilon_{j t}$

where $\alpha_{j}$ is a job fixed effect, $\beta_{t}$ is a period fixed effect common to all entry jobs, and the zero-mean error term $\varepsilon_{j t}$ represents temporary job-specific departures from the general period effect. The object of our analysis is to estimate a time series for $\beta_{t}$ and relate it to business cycle conditions.

If the data set were a "balanced panel" with every one of the $N$ sampled jobs observed in all periods, the estimation of $\beta_{t}$ would be particularly simple. With the mean of $\alpha_{j}$ normalized to zero, the least squares estimator of each $\beta_{t}$ would be simply 


$$
\hat{\beta}_{t}=\sum_{j=1}^{N} \log w_{j t} / N
$$

A figure that plotted the $\hat{\beta}_{t}$ time series along with a cycle indicator such as the unemployment rate would give an eyeball impression of the cyclical behavior of entry wages. A quantitative summary could be obtained by applying least squares to the regression of $\hat{\beta}_{t}$ on the unemployment rate with controls for secular time trends. If nonstationarity were a concern, the regression could be estimated in first differences instead of levels.

If the panel is unbalanced because observations of $w_{j t}$ are missing for some jobs in some years, it is still straightforward to estimate $\beta_{t}$ in equation (1) by applying least squares to the regression of the available observations of $\log w_{j t}$ on a vector of period dummy variables (for which the estimated coefficients are the $\hat{\beta}_{t}$ series) and a vector of job dummies. Alternatively, exactly the same $\hat{\beta}_{t}$ are obtained by applying least squares to the "de-meaned" regression of $\log w_{j t}$ on a vector of period dummies, in which each variable is expressed as a deviation from the job's time mean of the variable over the periods in which that job is observed. Either way of calculating $\hat{\beta}_{t}$ accounts for periodto-period changes in which jobs are in the sample by controlling for job fixed effects. This $\hat{\beta}_{t}$ series is the same as the sample means in equation (2) except that it is regression-adjusted for changes in sample composition. Again, the $\hat{\beta}_{t}$ series can be plotted along with the unemployment rate, and it can be regressed on the unemployment rate and time trend variables. 
Although complications inevitably arise in practice (as will be seen in the next section), the basic methodology is almost absurdly simple. That is what we like about it. Our method looks in a direct and transparent way at what employers actually do about entry wages over the business cycle.

\section{An Application to Firm-Level Data from Portugal}

\section{A. Description of the data}

In this section, we illustrate our method for measuring entry-wage cyclicality with an application to Portuguese data from 1982-2007. As shown in figure 1, Portugal's annual unemployment rate varied widely over that period, with peaks in the mid 1980's, mid 1990's, and mid 2000's. Another relevant feature of the Portuguese labor market over that period is its system of collective wage bargaining, which is explained in detail in Cardoso and Portugal (2005). The main message of that paper is that the bargained wage rates function as wage floors, with employers commonly paying wages above those floors. In the authors' words (p. 899), "the wage cushion works as a mechanism to overcome the constraints imposed by collective bargaining, allowing firms wide scope for action in their wage-setting policy.... This operation of institutional forces and market forces in the Portuguese economy may help explain why a typically European institutional framework is compatible with high wage flexibility and low unemployment.”

Our data come from Quadros de Pessoal, an annual mandatory census of all employers in Portugal (except that most of the public sector is excluded). The census was conducted in March in each year through 1993 and in October from 1994 on. 
Employer identification numbers enable longitudinal matching of employers. Information on every individual employed by the firm as of the census date is available for every year between 1982 and 2007 except 1990 and 2001. The employee information includes wage rate, detailed occupation code, and tenure with the firm. Employee identification numbers enable longitudinal matching of individual workers, even when they change employers, from 1986 on.

The data base suits our purposes very well. The combination of occupation and tenure information enables us to identify jobs into which each firm commonly recruits new employees, and we also observe the wages that the new employees in those jobs are paid. And by tracking those entry-job wages longitudinally, we can observe how they vary over the business cycle.

To identify a set of jobs into which, year after year, employers are observed to hire new workers, we apply a series of sample selection criteria. First, we consider only firms that employed at least 50 workers in at least five years of the 1982-2007 period. Second, we define jobs within firms in terms of five-digit occupation codes (such as supermarket shelf stocker, bank teller, clothing machine operator). When the same occupation code appears for different firms, we treat each occurrence as a different occupation/firm job. We link the occupation codes used from 1995 on with a different system of codes used through 1994, but, in the process, we lose some jobs for which the pre-1995 codes branch out into multiple post-1995 codes. ${ }^{6}$ Third, defining newly hired workers as those with no more than four months of tenure, we include a job in our main

\footnotetext{
${ }^{6}$ We also check that all workers in the job are at the same "job level," an eight-category variable coded as (1) apprentices, interns, trainees; (2) non-skilled professionals; (3) semi-skilled professionals; ... (8) top executives (top management). In most cases, this check is superfluous because it is unusual for the workers listed in the same occupation code within a firm to span more than one job level.
} 
sample of entry jobs if, in at least half the years the firm is present in the data base, the particular job accounted for at least three new hires and at least 10 percent of the firm's new hires in that year.

We therefore are focusing on what Doeringer and Piore (1971) called "port-ofentry" jobs. We do not mean, however, to subscribe to their stark description in which firms hire into only a limited number of such jobs, with other jobs filled almost exclusively by internal promotions and reassignments. More recent studies - such as the case study of a particular firm by Baker, Gibbs, and Holmstrom (1994) - have suggested that hiring from outside a firm can take place in a broad spectrum of jobs. Our focus on jobs that recurrently show new hires in the annual employer census is driven mainly by a pragmatic concern - to identify cyclical variation in hiring wages by job, we need those wages to be observed in multiple years spanning different business cycle conditions.

The main sample resulting from our selection criteria consists of 1,159 jobs in 998 firms. The firms are spread across a wide variety of industries, with the most common being manufacturing, construction, retail trade, hotels and restaurants, education, and "other business activities" (including cleaning, security, and temporary work agencies). Our panel of wages in entry jobs is "unbalanced," with a total of 8,804 job/years. The unbalancedness occurs because some firms begin or end between 1982 and 2007; because, in existing firms, it may happen that the workers observed in the job as of a particular census month include no one hired within the last four months; and because, as explained below, we sometimes are unable to identify a modal hiring wage. 
Table 1 displays sample size statistics by year along with the seasonally adjusted unemployment rate for the census month. ${ }^{7}$ The number of entry-job wages observed per year ranges from a low of 136 in 1982 to a high of 675 in 2003. With a total of 280,814 newly hired workers observed in the 8,804 job/years, on average more than 30 newly hired workers are observed per job/year. On account of procyclical hiring, the number of newly hired workers per observed entry job shows a clear tendency to be lower in years of high unemployment. Importantly, however, there is not a clear tendency for the number of observed entry jobs to decline in those years. If there were, we would need to worry that rigidity in hiring wages in some firms might be causing those firms to disappear from our sample in recession years because their hiring into their entry jobs dropped to zero. Instead, the pattern is that hiring declines but remains positive, so that we still observe hiring wages. ${ }^{8}$

Obviously, our analysis pertains to only a small fraction of all the jobs and firms encompassed in the Portuguese census of employers. It does, however, focus on those jobs that are most clearly recognizable as perennial entry jobs. Perhaps it is best to view our study as a sort of summary of 1,159 case studies of particular entry jobs.

As explained in the previous section, the dependent variable in our first-stage regressions is the typical logarithmic real hiring wage in job $j$ in period $t$. The wage measure we start with is each newly hired worker's monthly base pay (“corresponding to the normal hours of work") divided by the worker's normal monthly hours. We use

\footnotetext{
${ }^{7}$ These are the Eurostat unemployment rates reported at http://sdw.ecb.europa.eu/quickview.do?SERIES_KEY=132.STS.M.PT.S.UNEH.RTT000.4.000 as of June 2009. As these go back only to 1983, for March 1982 we use the first-quarter unemployment rate from Statistics Portugal.

${ }^{8}$ We thank David Card, Jonathan Guryan, and Steven Rivkin for raising this issue at the NBER Summer Institute. Note that, if we treated workers rather than jobs as our unit of analysis, variation in the number of hires per job could cause problems of endogenous sample selection.
} 
Statistics Portugal's monthly consumer price index (for March through 1993, for October afterwards) to convert this wage to real terms. Our main measure of the typical log hiring wage in a job/year is the modal value (with log wages measured to two decimal places). As mentioned above, we have dropped job/years in which we did not identify a modal wage. This occurred because of ties, most often because the job/year contained only two newly hired workers who received different wages. Figure 2 displays, for the 280,814 newly hired workers in our sample, the histogram of the difference between the worker's log wage and the modal log hiring wage in the job/year. As the figure shows, typically most of the newly hired workers in a job/year are paid at the modal rate.

\section{B. Empirical Analysis}

As explained in section III.B, we begin by estimating the year effects $\beta_{t}$ in equation (1) by applying least squares to the regression of the logarithm of job-specific real entry wages $w_{j t}$ on year dummy variables with controls for job fixed effects. As discussed in section III.B, if the panel of entry jobs were balanced with entry wages observed for all jobs in all periods, the estimated year effects would be simply $\hat{\beta}_{t}=\sum_{j=1}^{N} \log w_{j t} / N$. With our highly unbalanced panel, our estimates essentially regression-adjust that simple statistic for year-to-year changes in sample composition.

The resulting $\hat{\beta}_{t}$ series is plotted in figure 3, with the value for 1982 normalized to zero. Recall from section IV.A that the series pertains to March for the observations from 1982 through 1993, it pertains to October for the observations from 1994 through 2007, and it is missing the years 1990 and 2001. The figure also displays the seasonally 
adjusted unemployment rates for the corresponding months. Eyeballing the figure in a way that takes account of the upward secular trend in wages gives the impression that the entry-wage series and the unemployment rate are inversely related, but that the relationship is very loose.

As discussed in section III.B, we can quantify the cyclicality of entry wages by estimating regressions of the $\hat{\beta}_{t}$ time series on the unemployment rate and secular time trend controls. The first row of table 2 shows the estimated coefficient of the unemployment rate when this regression controls for a linear time trend and is estimated by weighted least squares (weighting by the number of entry jobs observed per year, in an effort to correct for the heteroskedasticity resulting from the wide variation in the peryear sample size). The procyclical coefficient estimate of -1.79 (with estimated standard error 0.39$)^{9}$ implies that, when the unemployment rate is one point higher (say, .07 instead of .06), real entry wages tend to be about 1.8 percent lower.

Heteroskedasticity diagnostics applied to the residuals suggest that the weighting procedure is reasonable, but in the next row of table 2 we use ordinary least squares instead of weighted least squares. The resulting coefficient estimate, -1.66 (with estimated standard error 0.49), is close to the weighted result. In the third row, we apply ordinary least squares to the first-differenced version of the regression. A linear time trend in levels implies that, in first differences, we need to control for the varying time interval between adjacent observations, which is usually 12 months but is 24 months for

\footnotetext{
${ }^{9}$ The reported standard error estimates are the old-fashioned kind, i.e., not corrected for heteroskedasticity or serial correlation. Serial correlation diagnostics indicate a first-order autocorrelation of about 0.4 and negligible second- and third-order autocorrelations. Despite having only 24 time series observations in our second-stage regressions, we have experimented with Newey-West standard error estimation robust to heteroskedasticity and first-order serial correlation. The resulting standard error estimates are very close to the old-fashioned ones.
} 
the 1989-1991 and 2000-2002 changes and 19 months for the change from March 1993 to October 1994. The resulting estimate, $-1.88(0.89)$, is a little more procyclical than the previous estimates.

In the fourth row, we revert to the analysis in the first row except that, as a simple check for dynamics, we include the 12-month lag of the unemployment rate as an additional regressor. ${ }^{10}$ The estimated coefficient of the lagged term, $-0.15(0.78)$, is small and statistically insignificant, and the estimated coefficient of the contemporaneous term, $-1.84(0.73)$, is significantly procyclical. Combining the estimates, the implied wage response to a one-point increase in the unemployment rate in both periods is -1.99.

In the fifth row, we redo the regression from row 1 except that we control for a quadratic time trend. The estimated coefficient of the squared trend variable is statistically insignificant, and the estimated coefficient of the unemployment rate, -1.54 (0.54), becomes a little less procyclical.

The next five rows repeat the analysis from row 1 but with alternative approaches to the first-stage estimation of the $\hat{\beta}_{t}$ series. In the sixth row, instead of representing the "typical” job/year wage $w_{j t}$ with the modal wage of new hires, we use their average wage. In the second-stage regression, this results in a slightly more procyclical estimate of -1.83 (0.46). This analysis still uses the individual wage measure described in section IV.A - the worker’s monthly base pay (“corresponding to the normal hours of work”) divided by the worker's normal monthly hours. In the seventh and eighth rows, we use alternative wage measures. In the seventh row, we use the average of a wage measure

\footnotetext{
${ }^{10}$ The analysis of Portuguese wage cyclicality in Carneiro, Guimarães, and Portugal (2009) uses only a one-year lag of the unemployment rate and does not report results for the contemporaneous unemployment rate.
} 
that adds in supplements "with a regular monthly nature, on account of subsistence, job transport, tenured-related or productivity, punctuality, hard-working/dangerous or dirty tasks, night shifts.” In the eighth row, we go further by measuring the worker's wage as the ratio of all the worker's pay in the census month (including overtime, bonuses, etc.) to all the worker's hours in the census month. The estimates based on these alternative wage measures, $-1.89(0.46)$ and $-1.79(0.51)$, are similar to those using our original base pay measure.

In the ninth row, we revert to using modal base pay, but we use a more inclusive sample of entry jobs in the first stage. Instead of requiring that the firms employ at least 50 workers in at least five years, we require that they employ at least 25. And instead of requiring that the job involves at least three new hires and at least 10 percent of the firm's new hires in at least half the years the firm is in the data base, we require at least two new hires and at least 10 percent of the firm's new hires in at least a quarter of the years. In the second stage, this results in a slightly more procyclical estimate of $-1.89(0.39)$. In the tenth row, we repeat the analysis in the first row except that we define newly hired workers as those with tenure of no more than three months instead of four. The resulting estimate, -1.80 (0.41), is almost identical to the one based on the four-month threshold.

Finally, because some analyses later in this section will involve only the years 1986-2007, in the last row we redo the analysis of row 1 with only those years. The resulting coefficient estimate, -1.61 (0.37), is a little less procyclical.

In general, throughout table 2, the estimated coefficients of the unemployment rate stay fairly close to -1.8 . Recognizing that, with procyclical labor force participation, the negative of the change in the unemployment rate is an attenuated version of 
proportional changes in employment, these estimates imply that the cyclical elasticity of entry wages and the cyclical elasticity of employment are of similar magnitudes. ${ }^{11}$ In that sense, our estimates of the procyclicality of entry wages are substantial. The result becomes more striking when one considers that the "cyclical upgrading" discussed in section III.A suggests that we may be underestimating the true procyclicality of entry wages. If, in a recession, employers are able to recruit a higher quality of workers at any given wage, the effective wage they pay per efficiency unit of labor is that much lower. ${ }^{12}$ In section $\mathrm{V}$, we will discuss further the macroeconomic implications of the magnitude of our estimates.

Another perspective on the estimates is that they are similar to the estimates of the overall cyclicality of workers' real wages in the U.S. literature that uses longitudinal data to relate workers' year-to-year changes in log wages to changes in the unemployment rate. $^{13}$ This similarity is surprising for two reasons. First, the estimates are for different countries. Second, they are measuring different facets of wage cyclicality. As discussed in section II, wage smoothing in long-term employment relationships could cause overall wages to be less procyclical than the hiring wages in entry jobs. On the other hand, as discussed in section III.A, workers' procyclical opportunities to move to higher-paying jobs (both within and across firms) contribute to estimates of workers' overall wage

\footnotetext{
${ }^{11}$ We have estimated Okun's Law-style regressions for Portugal over our sample period and found that a one-point increase in the unemployment rate is associated with a 1.75 percent reduction in the employment/population ratio. This procyclicality of employment is almost identical to the procyclicality we have estimated for real entry wages.

${ }^{12}$ So far, our only empirical exploration of this possibility with the Portuguese data has been to re-estimate some of the regressions in table 2 with average years of education of newly hired workers, instead of their log hiring wage, as the dependent variable. In accordance with the cyclical upgrading story, these estimates do show countercyclicality in the education of new hires, but the statistical significance of the estimates is sensitive to the specification of secular trends.

${ }^{13}$ See Bils (1985), Solon, Barsky, and Parker (1994), and the literature review in Solon, Barsky, and Parker (1992).
} 
procyclicality, while our estimates of entry-wage cyclicality are designed to hold jobs constant.

To address the first issue of between-country differences, in table 3 we use longitudinal worker data from the Portuguese census of employers to replicate the analyses in the U.S. longitudinal literature. In the tradition of Bils (1985), we estimate the regression of workers' year-to-year change in log real wages on change in the unemployment rate. Following Solon, Barsky, and Parker (1994), we break the estimation into two steps. In the first stage, we apply ordinary least squares to the regression of the worker's change in log real wages on year dummy variables and change in the worker's squared age, which belongs in the regression if the log wage/age profile is quadratic in levels. In the second stage, much as in the third row of table 2, we apply ordinary least squares to the regression of the estimated year effects on change in the unemployment rate and the length of the time interval between the adjacent censuses. ${ }^{14}$ The estimates are based on the period 1986-2007 because worker identifiers are not available before 1986 .

The resulting coefficient estimate for the unemployment rate, shown in the first row of table 3 , is -1.47 (with estimated standard error 0.42 ). This estimate is slightly less procyclical than the entry-wage counterpart for 1986-2007 shown in the last row of table 2. This suggests that, between the two factors that cause wage cyclicality from the workers’ perspective to differ from cyclicality of job-specific entry wages, the wagesmoothing factor is at least as important as the cyclical-upgrading factor. The estimate of

\footnotetext{
${ }^{14}$ We apply ordinary instead of weighted least squares in the second stage for reasons discussed in Dickens (1990). In our worker-level analysis, as opposed to the entry-job analysis in table 2, our first-stage estimation involves millions of observations. As a result, sampling error in the estimated year effects is inconsequential, and the error term in the second-stage regression is dominated by unobserved time effects common to all workers.
} 
-1.47, which is based on both male and female workers, is similar to the estimates for male workers in the U.S. longitudinal literature and higher than those for female workers. Furthermore, it is based on the same measure of workers' wages used in most of our entry-wage analyses - the ratio of the worker's monthly base pay to the worker's normal monthly hours. This measure leaves out overtime pay and other such non-base payments, which typically are included in the wage measures used in the U.S. longitudinal literature. In the second row of table 3 , as in the eighth row of table 2 , we include such pay by measuring the wage as the ratio of the worker's total monthly pay to the worker's total monthly hours. The resulting coefficient estimate for the unemployment rate, -1.72 (0.41), is even more procyclical. The substantial procyclicality of real wages in Portugal accords with the conclusion of Cardoso and Portugal (2005), mentioned at the beginning of section IV.A, that "wage cushions" above the wage floors prescribed in collective bargaining enable flexible wages in Portugal.

As discussed in sections II and III.A, the wage cyclicality literature based on longitudinal worker data has estimated particularly strong wage procyclicality for workers who change employers and more moderate procyclicality for workers who stay with the same employer. In the third row of table 3, we redo the estimation in row 1 with a sample restricted to workers who change employers between censuses. As in the previous literature, we find particularly procyclical wages for changers, with an estimated unemployment rate coefficient of $-2.64(0.41) .{ }^{15}$ Of course, the wage procyclicality for

\footnotetext{
${ }^{15}$ The closest counterpart to this estimate in the analysis of the 1986-2005 Portuguese data by Carneiro, Guimarães, and Portugal (2009) pertains to male "accessions," i.e., men with employer tenure of less than a year (who may or may not have been employed with another firm a year earlier). Carneiro et al. apply ordinary least squares in one stage to a levels regression of the worker's log wage (deflated by a lagged version of the consumer price index) on the one-year lag of the unemployment rate, a quadratic in time, a quadratic in age, and controls for worker fixed effects. The estimated coefficient of their unemployment
} 
workers who change employers is expected to exceed other measures of wage procyclicality because, for this group of workers, cyclical upgrading/downgrading is especially salient and wage smoothing is not a factor.

In the last row of table 3, we redo the row 1 analysis for a sample restricted to workers who stay with the same employer from one census to the next. In the first-stage regression, we control for changes in the squares of both age and tenure with employer. The second-stage estimate of the unemployment rate coefficient, $-1.43(0.44)$, is almost as procyclical as our estimate of overall wage cyclicality and somewhat less procyclical than most of our estimates of entry-wage cyclicality. ${ }^{16}$ The former comparison is a little surprising because, in the U.S. literature, the estimates of stayers' wage cyclicality usually are noticeably less than the estimates of overall wage cyclicality. ${ }^{17}$ With respect to the latter comparison, the wage-smoothing factor for stayers may be partly offset by cyclical upgrading of stayers across jobs within firms.

To summarize, longitudinal worker-based estimates of real wage cyclicality in Portugal are fairly similar to those in the U.S. literature, with the Portuguese estimates appearing a little more procyclical. In Portugal, however, unlike the United States at present, it is possible to use detailed employer/employee longitudinal data to conduct a direct and transparent analysis of the cyclical behavior of wages paid to newly hired workers in a large number of entry jobs. As discussed in section III, these data are better suited for assessing recent theories of firms’ practices vis-à-vis setting hiring wages. Our

variable is -2.73 . See our footnote 5 for a discussion of our concerns about the way in which Carneiro et al. pool their estimation of the cyclicality in accession wages with the cyclicality of other wages.

${ }^{16}$ In the study described in the preceding footnote, Carneiro, Guimarães, and Portugal (2009) also report results for male stayers, for whom the estimated coefficient of the one-year lag of the unemployment rate is -1.50 .

${ }^{17}$ But some studies - such as Solon, Barsky, and Parker (1994) and Shin and Solon (2007) - report only moderate differences. 
analyses of the Portuguese data have produced a robust finding that real entry wages by job tend to be about 1.8 percent lower when the unemployment rate is one percentage point higher.

\section{$\underline{\text { V. Summary and Discussion }}$}

Using longitudinally matched data from Portugal's annual census of employers, we have tracked the cyclical behavior of the real wages paid to newly hired employees in over a thousand jobs. We hope that eventually our methodology will be applied to additional countries as the requisite data become available.

Our estimates suggest that real entry wages in Portugal tend to be about 1.8 percent lower when the unemployment rate is one percentage point higher. As noted in section IV.B, this procyclicality in entry wages is substantial in the sense that the cyclical elasticity of this price variable is of approximately the same magnitude as the cyclical elasticity of employment. This finding, like practically all the longitudinal evidence on workers' wage cyclicality, counters a view often stated by influential macroeconomists that wages are much less cyclical than employment and unemployment.

One reason this finding matters is that some recent (as discussed in section II) and older attempts at theoretically explaining large cyclical changes in unemployment have emphasized rigidity of wages. Like most recent studies of other aspects of wage cyclicality, our study of real entry wages in Portugal has found that wages are not rigid, but rather respond considerably to business cycle conditions. Of course, this finding does not preclude that, in some sense, wages are "insufficiently" variable. Pursuing that idea, however, will require not a theory of wage rigidity, but a theory of why wages are not 
even more variable than they are. ${ }^{18}$ Putting the point another way, the very existence of large cyclical fluctuations in employment and unemployment indicates that wages do not vary enough to prevent those fluctuations. The continuing challenge to macroeconomic theorists is to develop a logically coherent and empirically relevant explanation of why employment, unemployment, and wages vary over the business cycle in the ways that they actually do.

Finally, returning to the question posed in section II, can the Mortensen-Pissarides model in particular account for the cyclical variability of unemployment in light of the magnitude of the entry-wage cyclicality that we have found? As discussed in section II, the answer depends not only on the cyclicality in hiring wages, but also on the persistence of those wages as the worker/employer match continues. At one extreme, if workers hired at a low wage during a recession are somehow locked into a permanent employment relationship at a perpetually low wage, the labor cost relevant to employers' recruiting decisions could be as cyclical as, or even more cyclical than, the initial hiring wage. At the other extreme, if the shortfall in hiring wages during a recession vaporizes soon after the employment relationship is initiated (either because the cheaply-hired workers quit or because retaining them requires substantial raises once the recession eases), cyclicality in the initial hiring wage might have only trivial impact on hiring decisions. Thus, assessing the allocative importance of initial hiring wages in the Mortensen-Pissarides model (or, for that matter, any model that recognizes the prevalence of long-term employment relationships) will require a deeper understanding of the durability of employment relationships, the evolution of wages and productivity in

\footnotetext{
${ }^{18}$ Hall and Milgrom (2008), Kennan (forthcoming), Snell and Thomas (forthcoming), and Perry and Solon (1985) are examples of steps in that direction.
} 
those relationships, and the dependence of both on current, past, and anticipated business cycle conditions. The empirical literature pioneered by Beaudry and DiNardo (1991), which is summarized in Thomas and Worrall (2007), has begun to explore these issues, and we believe further research in that area could be highly productive. 


\section{$\underline{\text { References }}$}

Baker, George, Michael Gibbs, and Bengt Holmstrom. 1994. “The Internal Economics of the Firm: Evidence from Personnel Data.” Quarterly Journal of Economics, 109(4): 881-919.

Barro, Robert J. 1977. “Long-Term Contracting, Sticky Prices, and Monetary Policy.” Journal of Monetary Economics, 3(3): 305-16.

Beaudry, Paul, and John DiNardo. 1991. “The Effect of Implicit Contracts on the Movement of Wages over the Business Cycle: Evidence from Micro Data.” Journal of Political Economy, 99(4): 665-88.

Becker, Gary S. 1962. “Investment in Human Capital: A Theoretical Analysis.” Journal of Political Economy, 70(5): S9-49.

Bewley, Truman F. 1999. Why Wages Don't Fall during a Recession. Cambridge, MA: Harvard University Press.

Bils, Mark J. 1985. "Real Wages over the Business Cycle: Evidence from Panel Data.” Journal of Political Economy, 93(4): 666-89.

Boldrin, Michele, and Michael Horvath. 1995. "Labor Contracts and Business Cycles.” Journal of Political Economy, 103(5): 972-1004.

Cardoso, Ana Rute, and Pedro Portugal. 2005. “Contractual Wages and the Wage Cushion under Different Bargaining Settings.” Journal of Labor Economics, 23(4): 875-902.

Carneiro, Anabela, Paulo Guimarães, and Pedro Portugal. 2009. "Real Wages and the Business Cycle: Accounting for Worker and Firm Heterogeneity.” Unpublished.

Devereux, Paul J. 2001. “The Cyclicality of Real Wages within Employer-Employee 
Matches.” Industrial and Labor Relations Review, 54(4): 835-50.

Devereux, Paul J. 2004. “Cyclical Quality Adjustment in the Labor Market.” Southern Economic Journal, 70(3): 600-15.

Devereux, Paul J., and Robert A. Hart. 2006. "Real Wage Cyclicality of Job Stayers, Within-Company Job Movers, and Between-Company Job Movers.” Industrial and Labor Relations Review, 60(1): 105-19.

Dickens, William T. 1990. "Error Components in Grouped Data: Is It Ever Worth Weighting?” Review of Economics and Statistics, 72(2): 328-33.

Doeringer, Peter B., and Michael J. Piore. 1971. Internal Labor Markets and Manpower Analysis. Lexington, MA: D. C. Heath.

Gertler, Mark, and Antonella Trigari. 2009. "Unemployment Fluctuations with Staggered Nash Wage Bargaining.” Journal of Political Economy, 117(1): 38-86.

Haefke, Christian, Marcus Sonntag, and Thijs van Rens. 2008. "Wage Rigidity and Job Creation.” Discussion Paper No. 3714, IZA.

Hall, Robert E. 1980. “Employment Fluctuations and Wage Rigidity.” Brookings Papers on Economic Activity, 1980(1): 91-123.

Hall, Robert E. 2005. “Employment Fluctuations with Equilibrium Wage Stickiness.” American Economic Review, 95(1): 50-65.

Hall, Robert E., and Paul R. Milgrom. 2008. “The Limited Influence of Unemployment on the Wage Bargain.” American Economic Review, 98(4): 1653-74.

Kennan, John. Forthcoming. "Private Information, Wage Bargaining and Employment Fluctuations.” Review of Economic Studies.

Keynes, John Maynard. 1936. The General Theory of Employment, Interest, and Money. 
London: Macmillan.

Kudlyak, Marianna. 2007. “The Cyclicality of the User Cost of Labor with Search and Matching.” Unpublished.

Kudlyak, Marianna. 2009. “The Cyclical Price of Labor When Wages Are Smoothed.” Unpublished.

Martins, Pedro S. 2007. "Heterogeneity in Real Wage Cyclicality.” Scottish Journal of Political Economy, 54(5): 684-98.

McLaughlin, Kenneth J., and Mark Bils. 2001. “Interindustry Mobility and the Cyclical Upgrading of Labor.” Journal of Labor Economics, 19(1): 94-135.

Mortensen, Dale T., and Christopher A. Pissarides. 1994. “Job Creation and Job Destruction in the Theory of Unemployment.” Review of Economic Studies, 61(3): 397-415.

Okun, Arthur M. 1973. “Upward Mobility in a High-Pressure Economy.” Brookings Papers on Economic Activity, 1973(1): 207-52.

Perry, Motty, and Gary Solon. 1985. “Wage Bargaining, Labor Turnover, and the Business Cycle: A Model with Asymmetric Information.” Journal of Labor Economics, 3(4): 421-33.

Pissarides, Christopher A. 2009. “The Unemployment Volatility Puzzle: Is Wage Stickiness the Answer?” Econometrica, 77(5): 1339-69.

Reder, Melvin W. 1955. “The Theory of Occupational Wage Differentials.” American Economic Review, 45(5): 833-52.

Reynolds, Lloyd G. 1951. The Structure of Labor Markets. New York: Harper \& Brothers. 
Rudanko, Leena. 2009. "Labor Market Dynamics under Long-Term Wage Contracting." Journal of Monetary Economics, 56(2): 170-83.

Shimer, Robert. 2004. “The Consequences of Rigid Wages in Search Models.” Journal of the European Economic Association, 2(2-3): 469-79.

Shimer, Robert. 2005. "The Cyclical Behavior of Equilibrium Unemployment and Vacancies.” American Economic Review, 95(1): 25-49.

Shin, Donggyun. 1994. “Cyclicality of Real Wages among Young Men.” Economics Letters, 46(2): 137-42.

Shin, Donggyun, and Gary Solon. 2007. “New Evidence on Real Wage Cyclicality within Employer-Employee Matches.” Scottish Journal of Political Economy, 54(5): 648-60.

Snell, Andy, and Jonathan P. Thomas. Forthcoming. "Labor Contracts, Equal Treatment, and Wage-Unemployment Dynamics.” American Economic Journal: Macroeconomics.

Solon, Gary, Robert Barsky, and Jonathan A. Parker. 1992. "Measuring the Cyclicality of Real Wages: How Important Is Composition Bias?” Working Paper No. 4202, National Bureau of Economic Research.

Solon, Gary, Robert Barsky, and Jonathan A. Parker. 1994. "Measuring the Cyclicality of Real Wages: How Important Is Composition Bias?” Quarterly Journal of Economics, 109(1): 1-25.

Solon, Gary, Warren Whatley, and Ann Huff Stevens. 1997. "Wage Changes and Intrafirm Job Mobility over the Business Cycle: Two Case Studies.” Industrial and Labor Relations Review, 50(3): 402-15. 
Thomas, Jonathan P., and Tim Worrall. 1988. "Self-Enforcing Wage Contracts.” Review of Economic Studies, 55(4): 541-54.

Thomas, Jonathan P., and Tim Worrall. 2007. "Limited Commitment Models of the Labour Market.” Scottish Journal of Political Economy, 54(5): 750-73.

Wooldridge, Jeffrey M. 2002. Econometric Analysis of Cross Section and Panel Data. Cambridge, MA: MIT Press. 
Figure 1. Annual Unemployment Rates in Portugal, 1982-2007

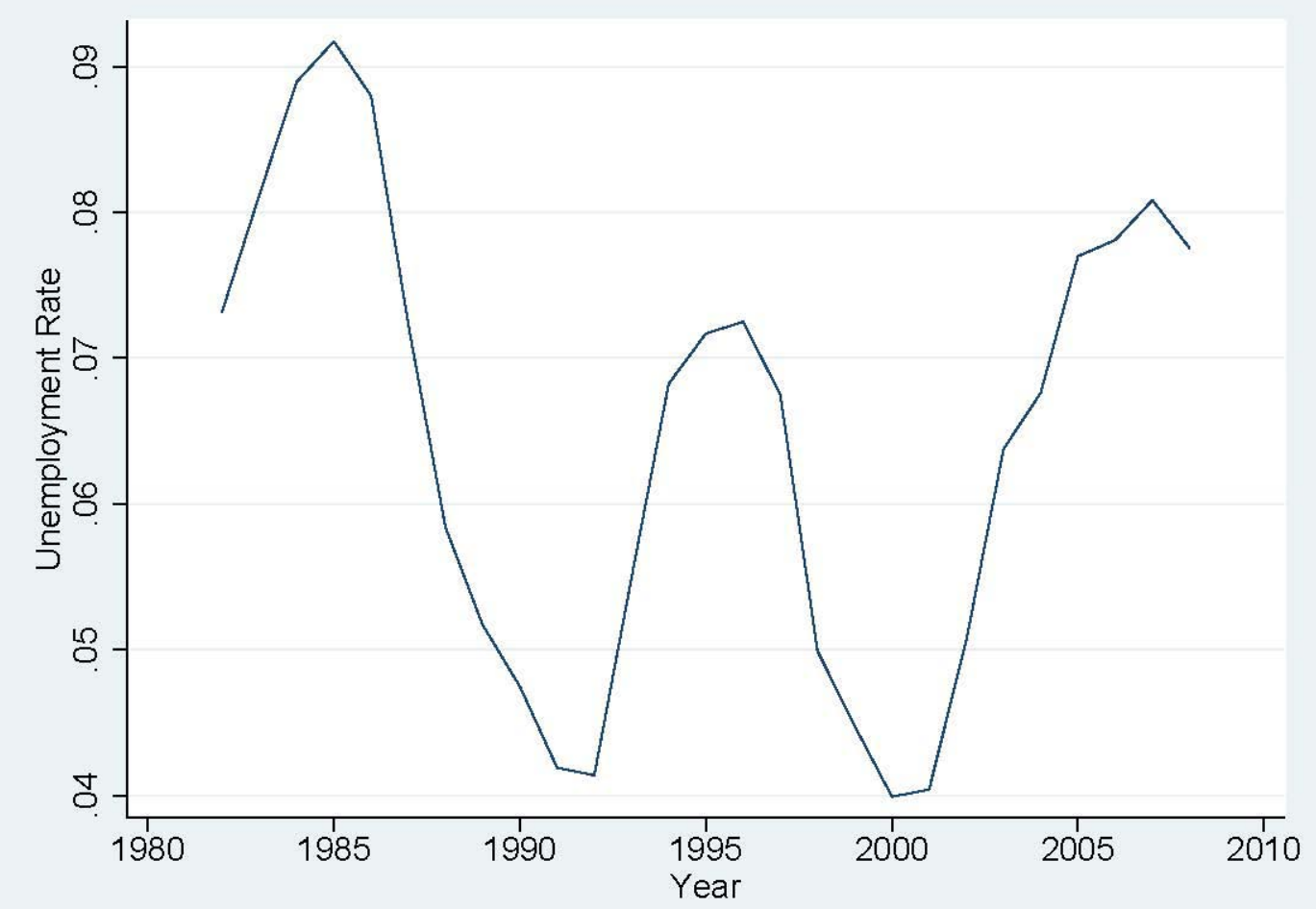


Figure 2. Sample Distribution of Difference between Individual Worker's Log Wage and Modal Log Hiring Wage in Job/Year

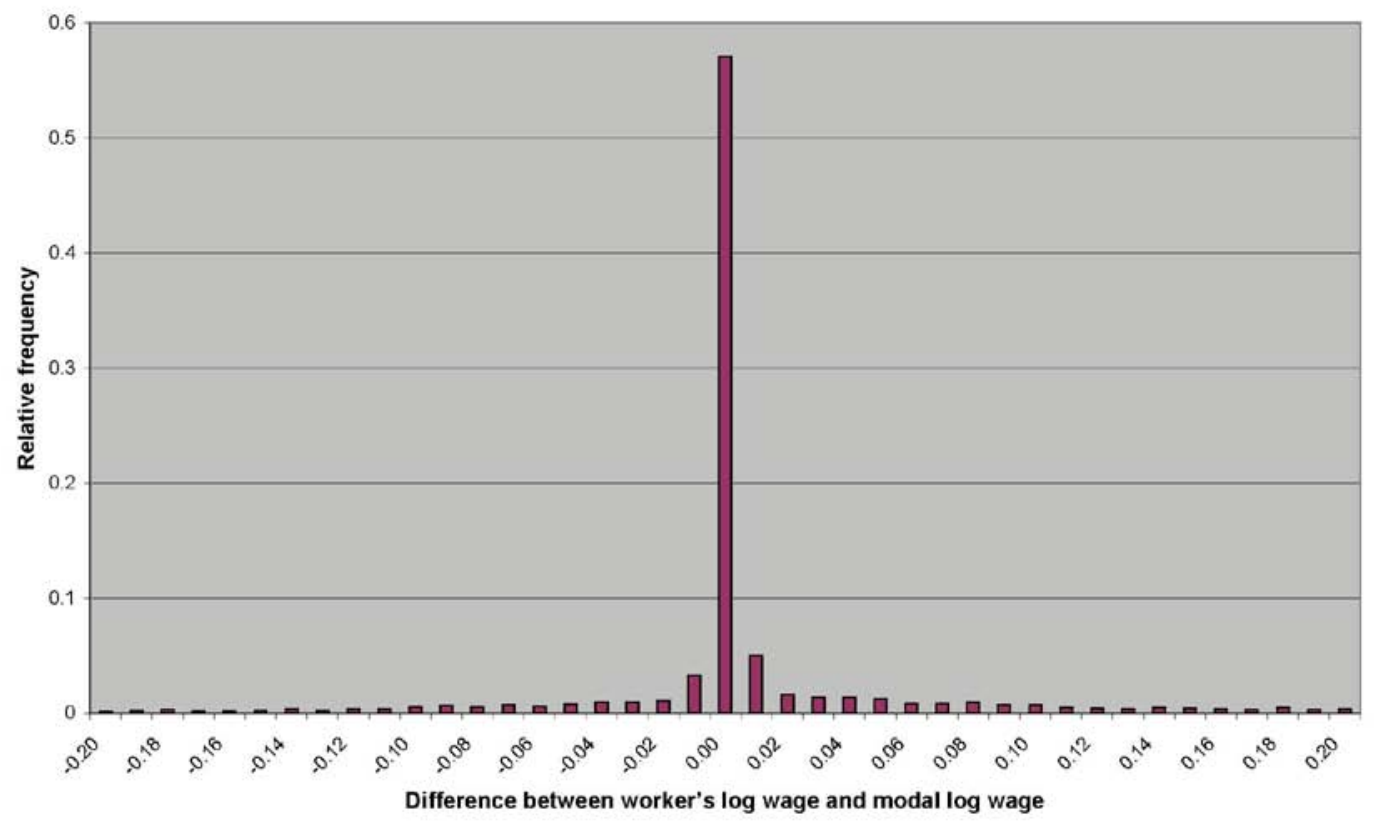


Figure 3. Estimated Period Effects for Log Entry Wages in Available Months and Corresponding Unemployment Rates, March 1982-October 2007

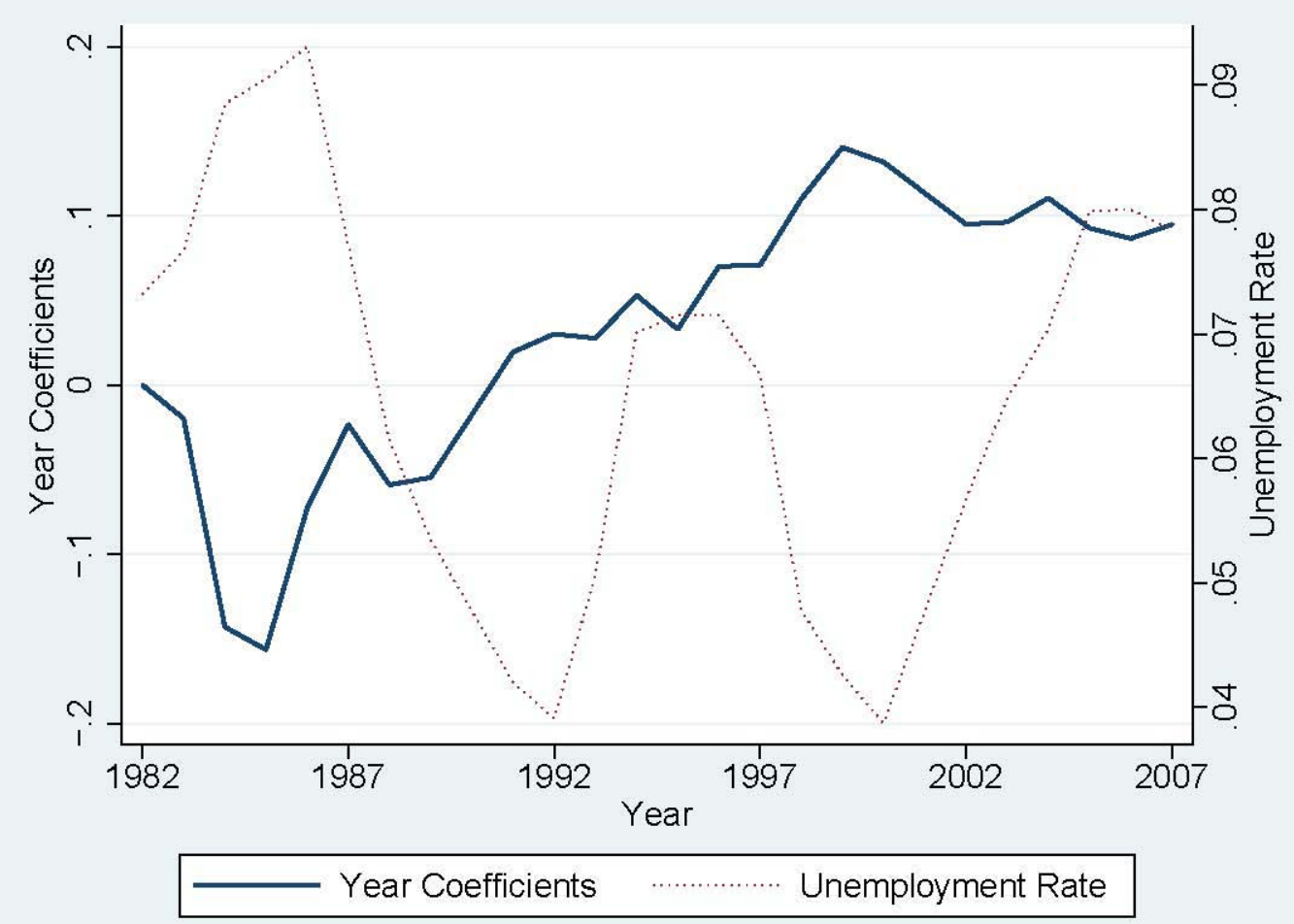


Table 1. Sample Sizes by Year

\begin{tabular}{|c|c|c|c|}
\hline Year & $\begin{array}{c}\text { Number of Entry } \\
\text { Jobs }\end{array}$ & $\begin{array}{c}\text { Number of Newly } \\
\text { Hired Workers }\end{array}$ & $\begin{array}{c}\text { Seasonally Adjusted } \\
\text { Unemployment Rate } \\
\text { in Census Month }\end{array}$ \\
\hline 1982 & 136 & 2,745 & 7.32 \\
\hline 1983 & 160 & 3,831 & 7.67 \\
\hline 1984 & 138 & 2,876 & 8.85 \\
\hline 1985 & 178 & 2,838 & 9.05 \\
\hline 1986 & 211 & 3,185 & 9.31 \\
\hline 1987 & 218 & 4,144 & 7.71 \\
\hline 1988 & 226 & 4,033 & 6.14 \\
\hline 1989 & 248 & 6,385 & 5.35 \\
\hline 1991 & 239 & 6,680 & 4.20 \\
\hline 1992 & 258 & 8,412 & 3.91 \\
\hline 1993 & 266 & 7,261 & 5.06 \\
\hline 1994 & 302 & 9,065 & 7.01 \\
\hline 1995 & 339 & 9,711 & 7.15 \\
\hline 1996 & 351 & 10,296 & 7.15 \\
\hline 1997 & 371 & 11,763 & 6.68 \\
\hline 1998 & 448 & 15,100 & 4.78 \\
\hline 1999 & 467 & 14,510 & 4.26 \\
\hline 2000 & 506 & 18,731 & 3.87 \\
\hline 2002 & 539 & 18,389 & 5.67 \\
\hline 2003 & 675 & 26,641 & 6.48 \\
\hline 2004 & 652 & 21,328 & 7.04 \\
\hline 2005 & 657 & 24,361 & 7.99 \\
\hline 2006 & 637 & 22,004 & 8.00 \\
\hline 2007 & 582 & 26,525 & 7.84 \\
\hline Total & 8,804 & 280,814 & \\
\hline
\end{tabular}


Table 2. Estimates of Cyclicality of Log Entry Wages in Portugal, 1982-2007

\begin{tabular}{|c|c|}
\hline Estimation Method & $\begin{array}{l}\text { Estimated Coefficient of Unemployment } \\
\text { Rate (and Estimated Standard Error) }\end{array}$ \\
\hline $\begin{array}{l}\text { 1. Weighted least squares for regression of } \\
\text { log modal entry wage year effects on } \\
\text { unemployment rate and linear time trend }\end{array}$ & $\begin{array}{l}-1.79 \\
(0.39)\end{array}$ \\
\hline 2. Same as (1) but ordinary least squares & $\begin{array}{l}-1.66 \\
(0.49)\end{array}$ \\
\hline $\begin{array}{l}\text { 3. Ordinary least squares for first } \\
\text { differences }\end{array}$ & $\begin{array}{l}-1.88 \\
(0.89) \\
\end{array}$ \\
\hline $\begin{array}{l}\text { 4. Same as (1) with one-year lag of } \\
\text { unemployment rate as additional regressor }\end{array}$ & \begin{tabular}{|lc} 
Contemporaneous: & -1.84 \\
& $(0.73)$ \\
Lagged: & -0.15 \\
& $(0.78)$
\end{tabular} \\
\hline 5. Same as (1) with quadratic time trend & $\begin{array}{l}-1.54 \\
(0.54)\end{array}$ \\
\hline 6. Same as (1) with log average wage & $\begin{array}{l}-1.83 \\
(0.46)\end{array}$ \\
\hline $\begin{array}{l}\text { 7. Same as (6) with wage measure } \\
\text { combining base wage with regular } \\
\text { supplements }\end{array}$ & $\begin{array}{l}-1.89 \\
(0.48)\end{array}$ \\
\hline $\begin{array}{l}\text { 8. Same as (6) with wage measure } \\
\text { including all non-base pay }\end{array}$ & $\begin{array}{l}-1.79 \\
(0.51)\end{array}$ \\
\hline $\begin{array}{l}\text { 9. Same as (1) with more inclusive } \\
\text { definition of entry jobs }\end{array}$ & $\begin{array}{l}-1.89 \\
(0.39)\end{array}$ \\
\hline $\begin{array}{l}\text { 10. Same as (1) with new-hire criterion } \\
\text { reduced to three months of tenure }\end{array}$ & $\begin{array}{l}-1.80 \\
(0.41)\end{array}$ \\
\hline 11. Same as (1) for $1986-2007$ & $\begin{array}{l}-1.61 \\
(0.37)\end{array}$ \\
\hline
\end{tabular}


Table 3. Estimates from Regressions of Portuguese Workers' Change in Log Wages on Change in Unemployment Rate, 1986-1987 to 2006-2007

\begin{tabular}{|l|c|}
\hline Estimation Method & $\begin{array}{c}\text { Estimated Coefficient of Change in } \\
\text { Unemployment Rate (and Estimated } \\
\text { Standard Error) }\end{array}$ \\
\hline 1. All longitudinally matched workers, & -1.47 \\
with controls for age and time & $(0.42)$ \\
\hline 2. Same as (1) but with wage measure & -1.72 \\
including non-base pay & $(0.41)$ \\
\hline 3. Same as (1) but for sample restricted to & -2.64 \\
workers changing employers & $0.41)$ \\
\hline 4. Same as (1) but for sample restricted to & -1.43 \\
workers staying with same employer (with & $(0.44)$ \\
additional control for tenure with & \\
employer) & \\
\hline
\end{tabular}

